\title{
Analysis of Hyaluronidase Expression by qPCR in Egyptian Clinical Isolates of Staphylococcus aureus and Its Correlation with Phenotypic Plate Assay
}

\author{
Sarah A. Abdelkader, Mohammed El-Mowafy, Eman Abdelmegeed, Ramadan Hassan \\ Department of Microbiology and Immunology, Faculty of Pharmacy, Mansoura University, Mansoura, Egypt \\ Email: seven@mans.edu.eg
}

How to cite this paper: Abdelkader, S.A., El-Mowafy, M., Abdelmegeed, E. and Hassan, R. (2018) Analysis of Hyaluronidase Expression by qPCR in Egyptian Clinical Isolates of Staphylococcus aureus and Its Correlation with Phenotypic Plate Assay. Advances in Microbiology, 8, 614-624. https://doi.org/10.4236/aim.2018.87041

Received: May 11, 2018

Accepted: July 27, 2018

Published: July 30, 2018

Copyright $\odot 2018$ by authors and Scientific Research Publishing Inc. This work is licensed under the Creative Commons Attribution International License (CC BY 4.0).

http://creativecommons.org/licenses/by/4.0/

(c) (i) Open Access

\begin{abstract}
Hyaluronidase enzyme (HysA) is an extracellular enzyme that is considered to be an important virulence factor for Staphylococcus aureus. We screened the production of HysA enzyme in the spent media of Egyptian clinical isolates (32 isolates) via phenotypic plate assay. We found that $75 \%$ of the isolates (24 isolates) were able to produce HysA enzyme. We designed primers for qPCR analysis of hys $A$ mRNA expression that was derived from the alignment of hys $A$ gene sequences of 41 strains of $S$. aureus. The designed primers could be used for the amplification of hys $A$ in $79.2 \%$ of the isolates (19 isolates) that were positive for HysA production as demonstrated by phenotypic plate assay. A significant positive correlation, as indicated by Pearson correlation analysis $(\mathrm{r}=0.84$ at $\mathrm{P}<0.001$ ), was found between phenotypic plate assay and qPCR of mRNA expression of hysA in the investigated isolates of $S$. aureus. In conclusion, we analyzed for the first time hys $A$ mRNA expression via qPCR in $S$. aureus. Additionally, our work showed a good agreement between the phenotypic assay of HysA production via plate assay and hysA expression in $S$. aureus. The qPCR analysis of this study could be used as a more reliable quantitative method for hys $A$ expression analysis particularly in infected animal models of $S$. aureus.
\end{abstract}

\section{Keywords}

Hyaluronidase, qPCR, Staphylococcus aureus, Virulence Factor

\section{Introduction}

Staphylococcus aureus is a Gram positive bacterium that causes a diverse range 
of both community-associated and hospital-acquired infections [1] [2] [3]. $S$. aureus contains various virulence factors that consist of both surface-associated proteins and secreted proteins including hemolysins, immunomodulators and a number of exoenzymes [4] [5] [6].

Bacterial hyaluronidases (known as hyaluronate lyases) are a class of enzymes that degrade hyaluronic acid (HA) and to lower extent chondroitin and chondroitin sulfate [7] [8]. HA is a high molecular-weight polymer composed of alternating units of D-glucuronic acid and $\mathrm{N}$-acetylglucosamine [9]. This polymer is a major component of the extracellular matrix of human tissues and it is abundant in the skin, skeletal tissue, umbilical cord, lungs, heart valves, brain, blood, liver and a number of other tissues [10]. Moreover, it plays important roles for inflammation, water homeostasis, in addition to being an immune regulator [11] [12]. Hyaluronidases have been found to be virulence factors that are involved in the invasion, and penetration of tissues in many of Gram positive bacteria [9].

$S$. aureus is able to infect many tissues which contain high HA concentrations using HysA as a virulence factor [13] [14]. The expression of HysA by $S$. aureus can be assayed phenotypically by various methods e.g. plate assay [15], turbidemetry [16], viscometry [17], colorimetry [18] and zymography [19]. The disadvantages of these classical methods are that they often lack sensitivity, and selectivity, and require large amounts of samples [10]. Despite the vital role of hyaluronidase for $S$. aureus as a virulence factor, no study has analyzed the hys $A$ mRNA expression via qPCR which would be a more reliable and accurate method for quantitative analysis of hys $A$ expression particularly in infected animal models of $S$. aureus. Therefore, our main aim in this study was to analyze the expression of hys $A$ in $S$. aureus clinical isolates via qPCR and to correlate these results with the phenotypic plate assay. The $\mathrm{qPCR}$ analysis of hys $A$ expression will be a more reliable and accurate method for quantitative analysis of the enzyme expression particularly in infected animal models of $S$. aureus.

\section{Materials and Methods}

\subsection{Collection, Purification and Identification of $S$, aureus Isolates}

32 isolates of $S$. aureus (S1-S32) were collected from different sources (wounds, burns, and throat) obtained from Mansoura university hospitals, Egypt. This work was done after approval of the administrative authorities (Research Ethics Committee) in the Faculty of Pharmacy, Mansoura University, Egypt. The isolates were purified and confirmed as $S$. aureus by Gram staining and biochemical reactions (Mannitol salt agar, catalase, and coagulase) and using $S$. aureus Newman as a reference strain [20] that was kindly provided by Dr. Mohammed Youssef Ali (Associate professor of microbiology and immunology, faculty of pharmacy, Mansoura university). All bacterial strains were stored in brain heart infusion (BHI) broth medium containing $20 \%$ glycerol at $-80^{\circ} \mathrm{C}$, until further analyses were performed. 


\subsection{Spent Media Preparation}

Overnight cultures of different isolates in $\mathrm{BHI}$ broth were incubated at $37^{\circ} \mathrm{C}$ with shaking at $200 \mathrm{rpm}$. Later, subculturing into fresh BHI broth medium (starting $\mathrm{OD}_{630 \mathrm{~nm}}$ equivalent to $1.7 \times 10^{7} \mathrm{CFU} / \mathrm{ml}$ ) was performed with shaking at $200 \mathrm{rpm}$, and $37^{\circ} \mathrm{C}$. Samples $(1 \mathrm{ml})$ were taken at the required time point, and centrifuged at $3200 \mathrm{x}$ g for $5 \mathrm{~min}$. Spent media (supernatant containing the produced HysA enzyme) were filter sterilized and stored at $-80^{\circ} \mathrm{C}$ till further analyses.

\subsection{Screening and Quantitative Assay of the Hyaluronidase-Producing $S$, aureus Isolates Using Plate Assay Method}

The procedure of [8] was followed with minor modifications. Sterile glass plates (12 cm diameter) containing $1 \%$ agarose, $1 \%$ bovine serum albumin (BSA), and $0.4 \mathrm{mg} / \mathrm{ml}$ of HA (Sigma, H-1504) in $0.3 \mathrm{M}$ sodium phosphate buffer ( $\mathrm{pH} 5.3$ ) were prepared. After solidification of the agarose medium, wells $(7 \mathrm{~mm}$ diameter) were made aseptically, and $100 \mu \mathrm{l}$ of spent media were added into each well.

Plates were incubated for $24 \mathrm{~h}$ at $37^{\circ} \mathrm{C}$ before flooding with $2 \mathrm{M}$ acetic acid. Clear zones were observed against a background of opaque precipitated BSA conjugated to the undigested HA and their diameters were measured in millimeters. Hyaluronidase (Sanofi, $1500 \mathrm{IU}$ ) was used as a standard positive control and for construction of standard curve after dissolving in $500 \mu \mathrm{BHI}$ broth to obtain a final concentration of $3000 \mathrm{IU} / \mathrm{ml}$, where two fold serial dilutions from the concentration $3000 \mathrm{IU} / \mathrm{ml}$ till $5.8 \mathrm{IU} / \mathrm{ml}$ were prepared in BHI broth. Later, $100 \mu \mathrm{l}$ from each dilution was examined for its hyaluronidase as indicated above. The standard curve was constructed from plotting of the logarithmic concentration of standard hyaluronidase (3000 - $5.8 \mathrm{IU} / \mathrm{ml})$ and the clear zones of HA hydrolysis subtracted from the cup diameter (Figure 1). The hyaluronidase activity present in the spent medium of each isolate was expressed as $\mathrm{IU} / \mathrm{ml}$ according to the standard hyaluronidase (Figure 1).

\subsection{Primer Design via Multiple Sequence Alignment for Detection of Hyaluronidase Expression by Quantitative Real-Time-PCR (qPCR)}

Hyaluronidase DNA sequences of $41 \mathrm{~S}$. aureus strains were obtained from the GenBank database and aligned by using the multisequence alignment tool (Clustal omega) that is provided by EMBL-EBI website (Figure S1). For qPCR analysis for hyaluronidase expression, forward (Hyalq-F) and reverse (Hyalq- $\mathrm{R}$ ) primers (Table 1) were precisely designed from the conserved regions of the aligned sequences and with the consideration of the optimum GC\% (40\% - 60\%).

\subsection{RNA Isolation, cDNA Synthesis, and qPCR}

For qPCR analysis of hysA expression, the optimum time for RNA extraction was investigated by measurement of HysA activity in the spent media and the OD630nm at different time points (3, 5, 9, 24 h). For such optimization, two 

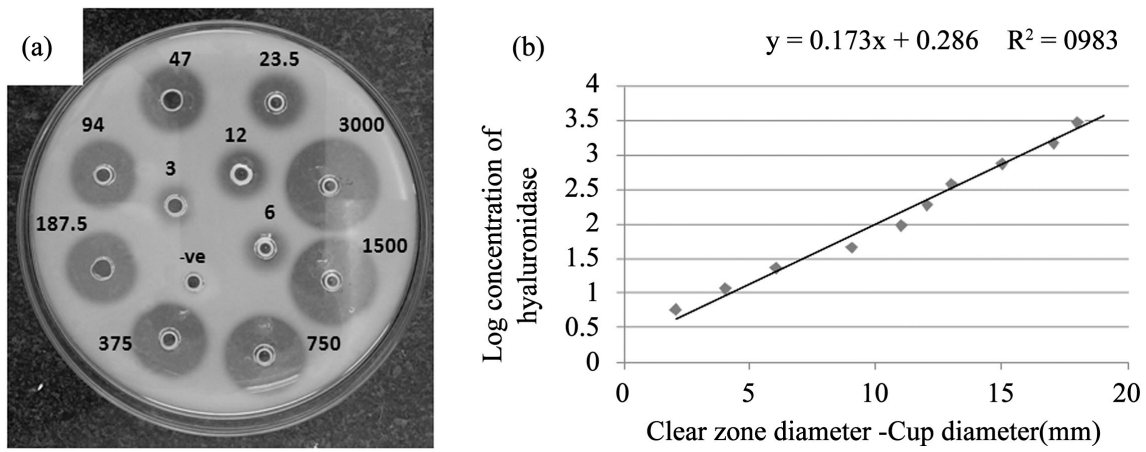

Figure 1. Plate assay of different concentrations (IU/ml) of the HysA (a) and standard curve for enzyme activity (b).

Table 1. Primers used in this study.

\begin{tabular}{|c|c|c|c|c|}
\hline Primer & Sequence $\left(5^{\prime}-3^{\prime}\right)$ & Relevance & $\begin{array}{l}\text { Amplicon size } \\
\text { (bp) }\end{array}$ & Reference \\
\hline Hyalq-F & GGTGCTTATGGCGTTGTACT & qPCR of $h y s A$ & \multirow{2}{*}{163} & \multirow{2}{*}{ This study } \\
\hline Hyalq-R & CGTGATAAATCCATCATTTCACC & expression & & \\
\hline GyrB-F & CCAGGTAAATTAGCCGATTGC & \multirow{2}{*}{$\begin{array}{l}\text { qPCR of } g y r B \\
\text { expression }\end{array}$} & \multirow{2}{*}{121} & \multirow{2}{*}{ [21] } \\
\hline GyrB-R & AAATCGCCTGCGTTCTAGAG & & & \\
\hline
\end{tabular}

F: Foward primer, R: Reverse primer.

strains were selected as representative samples; Newman, and S10.

Cell pellets were harvested from aliquots of $1.5 \mathrm{ml}$ at each specified time for RNA isolation and centrifuged at $3200 \mathrm{x}$ g and $4^{\circ} \mathrm{C}$ for $5 \mathrm{~min}$. Glass beads ( 150 $\mathrm{mg}, 0.25-0.5 \mathrm{~mm}$ diameter) [Roth, Carlsruhe, Germany] and $300 \mu \mathrm{l}$ of triazole reagent (Zymo research) were added to the cell pellet. The mixture was subjected to alternating intervals of vortexing $(30 \mathrm{sec})$ and immersion in ice $(30 \mathrm{sec})$ for total of $10 \mathrm{~min}$. Later, freezing at $-80^{\circ} \mathrm{C}(3 \mathrm{~min})$ and thawing at $37^{\circ} \mathrm{C}(3 \mathrm{~min})$ was performed 3 times. The disrupted cells were centrifuged at $3200 \mathrm{xg}$ and $4^{\circ} \mathrm{C}$ for $5 \mathrm{~min}$. RNA was precipitated according to the protocol of the triazole reagent company for isolation of RNA by traizole method. The precipitated RNA was dried, dissolved in $20 \mu \mathrm{l}$ RNAase free water, and stored at $-80^{\circ} \mathrm{C}$ till further analysis. The quality of RNA was checked by agarose gel electrophoresis and RNA concentration was determined using nanodrop.

The synthesis of cDNA from the purified RNA of different isolates was performed using the Quantitect Reverse Transcription kit (Qiagen, Hilden, Germany) according to the manufacturers' instructions. Real-time PCR was performed in $20 \mu \mathrm{l}$ reaction volumes using the Rotor-Gene Q (Qiagen) and 5x HOT FIREPol EvaGreen HRM Mix according to the manufacturers' instructions. Each reaction volume contained $4 \mu \mathrm{l} 5 \mathrm{x}$ HOT FIREPol EvaGreen HRM, $0.5 \mu \mathrm{l}$ forward ( $250 \mathrm{nM}$ final), $0.5 \mu$ reverse primer ( $250 \mathrm{nM}$ final), $13 \mu$ sterile water (PCR grade), and $2 \mu \mathrm{l}$ of template cDNA. The gene encoding GyrB was used as a reference gene and amplified using the GyrB-F and GyrB-R primers (Table 1). 
Negative control reactions without cDNA template were included in each PCR run. Additionally, strain S32 was included in each run as a control for the strains that were negative for HysA production by phenotypic assay. The PCR was performed using the following conditions: initial activation at $95^{\circ} \mathrm{C}$ for $12 \mathrm{~min}$, followed by 40 cycles of denaturation $\left(95^{\circ} \mathrm{C}\right.$ for $\left.12 \mathrm{sec}\right)$, annealing $\left(59^{\circ} \mathrm{C}\right.$ for $\left.20 \mathrm{sec}\right)$, and extension $\left(72^{\circ} \mathrm{C}\right.$ for $\left.20 \mathrm{sec}\right)$.

Melting curves were analyzed to check PCR specificity, and the absence of primer dimers. The PCR efficiency (E) of each primer pair was determined by making dilution series (undiluted, 1/5, 1/10,1/50, and 1/100) using cDNA of $S$. aureus strain Newman as a template. The cDNA sample of $S$. aureus strain Newman was used as a calibrator sample in all qPCR runs to minimize run-to-run variations. The threshold cycle (CT) values were calculated by the Rotor-Gene Q software, and exported to Excel for relative quantification analysis. To ensure the accuracy of amplification, all generated amplicons were separated by agarose gel electrophoresis in a $2 \%$ agarose gel, stained with ethidium bromide, and visualized on a UV transilluminator.

\subsection{Statistical Analysis}

Results were statistically analyzed using Excel program. The values for either concentration/OD630nm (Phenotypic assay) or the fold of change in RNA expression (Genotypic assay) were calculated as the average mean \pm SD of 3 independent experiments. The correlation between the phenotypic production of HysA, as indicated by plate assay, and the qPCR analysis of hys $A$ expression, was performed using the Pearson correlation analysis test.

\section{Results}

\subsection{Phenotypic Screening of HysA Production by the Clinical Isolates of $S$, aureus via Plate Assay}

Twenty four strains (S1-S24) out of 32 strains were able to produce HysA as indicated by the clear zones obtained from the plate assay. The concentration of hyaluronidase in the spent media was obtained from the standard curve of hyaluronidase enzyme (Figure 1), which was then normalized to the $\mathrm{OD}_{630 \mathrm{~nm}}$ of each individual culture (Concentration/ $\mathrm{OD}_{630 \mathrm{~nm}}$ ). The highest HysA producing strain was S10, followed by Newman as indicated in Table 2 .

\section{2. qPCR Analysis of hysA mRNA Expression in the HysA Producing Clinical Isolates of $S$, aureus}

As indicated in Figure 2, the highest production of HysA was detected after $3 \mathrm{~h}$ cultivation of subcultures of the strains; Newman and S10. Therefore, for qPCR analysis of hys $A$ mRNA expression, the RNA was isolated from the subcultures of the HysA producing isolates of $S$. aureus after $3 \mathrm{~h}$ cultivation.

The efficiency of amplification of hys $A$ and $\operatorname{gyr} B$ genes were 1.7 and 1.87 respectively, as determined by the software of Rotor gene Q. To correct for the 
difference between amplification efficiencies of both genes, the Paffl method [22] was used in this study to determine the relative expression of hys $A$ gene in different isolates using Newman as a calibrator strain. The fold of change (FC) in expression of hys $A$ in different clinical isolates relative to hys $A$ expression by Newman is shown as mean \pm SD of three independent experiments (Table 2).

Table 2. Phenotypic assay of HysA production and qPCR analysis of expression of hysA from different isolates of $S$. aureus. The values for either Concentration/ $/ \mathrm{OD}_{630 \mathrm{~nm}}$ or the fold of change are the average mean \pm SD of 3 independent experiments.

\begin{tabular}{|c|c|c|c|c|}
\hline \multicolumn{5}{|c|}{ Strains producing HysA and their hys $A$ expression could be detected by qPCR } \\
\hline \multirow[b]{2}{*}{ Strain } & \multicolumn{2}{|r|}{ Phenotypic assay } & \multicolumn{2}{|c|}{ Genotypic assay } \\
\hline & Rank & $\begin{array}{c}\text { Concentration } / \mathrm{OD}_{630 \mathrm{~nm}} \\
(\text { Mean } \pm \mathrm{SD})\end{array}$ & $\begin{array}{l}\text { Fold of change } \\
(\text { Mean } \pm S D)\end{array}$ & Rank \\
\hline S10 & 1 & $938.38 \pm 94.22$ & $127.86 \pm 3.315$ & 1 \\
\hline Newman & 2 & $397.00 \pm 4.24$ & 1 & 3 \\
\hline S5 & 3 & $322.29 \pm 52.03$ & $0.631 \pm 0.023$ & 4 \\
\hline S8 & 4 & $295.50 \pm 21.92$ & $0.579 \pm 0.028$ & 5 \\
\hline S3 & 5 & $273.65 \pm 75.87$ & $0.025 \pm 0.042$ & 17 \\
\hline S9 & 6 & $270.16 \pm 64.83$ & $0.326 \pm 0.027$ & 8 \\
\hline S7 & 7 & $236.37 \pm 19.28$ & $0.363 \pm 0.041$ & 7 \\
\hline S6 & 8 & $219.50 \pm 14.85$ & $2.243 \pm 0.604$ & 2 \\
\hline S2 & 9 & $215.62 \pm 23.46$ & $0.264 \pm 0.113$ & 9 \\
\hline S20 & 10 & $212.16 \pm 17.20$ & $0.175 \pm 0.004$ & 12 \\
\hline S4 & 11 & $201.30 \pm 15.99$ & $0.413 \pm 0.424$ & 6 \\
\hline $\mathrm{S} 13$ & 12 & $180.49 \pm 9.34$ & $0.190 \pm 0.083$ & 11 \\
\hline S1 & 13 & $145.31 \pm 7.51$ & $0.145 \pm 0.050$ & 13 \\
\hline S12 & 14 & $135.98 \pm 43.94$ & $0.226 \pm 0.134$ & 10 \\
\hline S23 & 15 & $107.50 \pm 17.68$ & $0.005 \pm 0.0006$ & 19 \\
\hline S21 & 16 & $107.30 \pm 10.32$ & $0.036 \pm 0.0078$ & 16 \\
\hline S11 & 17 & $99.15 \pm 12.93$ & $0.001 \pm 0.0003$ & 20 \\
\hline S22 & 18 & $74.87 \pm 10.08$ & $0.038 \pm 0.001$ & 15 \\
\hline S19 & 19 & $72.65 \pm 3.33$ & $0.013 \pm 0.002$ & 18 \\
\hline S18 & 20 & $52.64 \pm 10.42$ & $0.137 \pm 0.049$ & 14 \\
\hline \multicolumn{5}{|c|}{ Strains producing HysA and their hys $A$ expression could not be detected by qPCR } \\
\hline Strain & \multicolumn{4}{|c|}{ Concentration $/ \mathrm{OD}_{630 \mathrm{~nm}}($ Mean $\pm \mathrm{SD})$} \\
\hline S14 & \multicolumn{4}{|c|}{$66.8 \pm 15.77$} \\
\hline S15 & \multicolumn{4}{|c|}{$30.1 \pm 6.52$} \\
\hline S16 & \multicolumn{4}{|c|}{$20.2 \pm 5.43$} \\
\hline S17 & \multicolumn{4}{|c|}{$9.1 \pm 2.22$} \\
\hline S24 & \multicolumn{4}{|c|}{$63 \pm 14.34$} \\
\hline
\end{tabular}




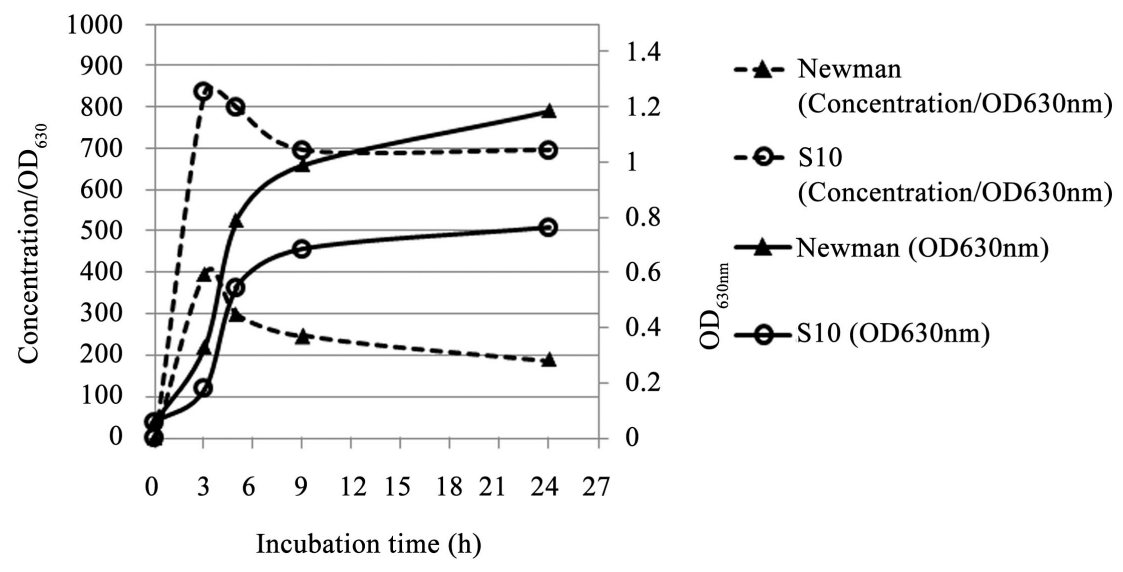

Figure 2. HysA production and growth curve of Newman and S10 strains at different time points of subculture cultivation.

\section{Discussion}

Few reports have focused on the study of hyaluronidase production by $S$. aureus, despite the importance of hyaluronidase enzyme as a virulence factor for Gram positive cocci [9]. Such reports were interested in either phenotypic screening of the enzyme production by different species of Staphylococcus [23] [24] [25], or investigation of its role in the virulence of $S$. aureus [8] [14].

In this work, we performed phenotypic analysis for HysA production by different clinical isolates using a plate assay. The plate assay showed that $75 \%$ of the isolates (24 out of 32 isolates) were able to produce hyaluronidase. In previous studies such percent was either $91.2 \%$ [23], 93\% [25] or 99.5\% [24].

The previous studies on genotypic analysis of hys $A$ in $S$. aureus were restricted on either the detection of the gene by Southern blot [25], DNA microarray [26] or semiquantitative analysis via Northern blot [8]. None of the previous studies tried to perform genotypic analysis of hys $A$ expression via qPCR. Therefore, we were interested in quantitative detection of hys $A$ mRNA expression via qPCR.

We determined the concentration/ $\mathrm{OD}_{630 \mathrm{~nm}}$ for HysA production at different time points for S10 and Newman strains (the 2 highest strains producing HysA as indicated from our preliminary investigations). As shown in Figure 2, the maximum productivity of the cells in both strains was found to be after $3 \mathrm{~h}$ of cultivation of the subcultures. Consequently, the optimum time for RNA extraction in this study was considered to be after $3 \mathrm{~h}$ cultivation in the early exponential phase of growth. We designed forward and reverse primers in the conserved regions of hys $A$ after alignment of the gene sequences of 41 strains of $S$. aureus from the Genbank (Figure S1). The primers were used for the qPCR analysis of the mRNA expression of hys $A$ in the isolates that were found to produce the enzyme after plate assay (24 out of 32 ). The ability of the designed primers to amplify hys $A$ was investigated through both the analysis of the expected amplicons via agarose gel electrophoresis and the amplification plots after performing qPCR in the Rotor-Gene Q. Our results showed that the designed primers successfully amplified the hysA gene in $79.2 \%$ of the HysA producing isolates (19 
out of 24 isolates) as demonstrated in Table 2. The last 19 isolates (target isolates) together with the Newman strain were used to investigate the correlation between the phenotypic assay via plate assay and the quantitative genotypic assay using qPCR. The reason that 5 isolates were associated with HysA production in the plate assay and could not be amplified by the designed primers, might be the presence of mutations in the conserved regions at which the primers bind in the hys $A$ gene.

Previous studies correlated the measured phenotypic character for different genes and their genetic expression in different organisms e.g. antimicrobial resistance genes [27] and virulence genes [28] in Pseudomonas aeruginosa, genes regulating metabolite concentrations in the yeast Saccharomyces cerevisiae [29], and scoC gene in Bacillus subtilis [30]. Similarly, we studied the correlation between phenotypic plate assay and qPCR analysis for the hys $A$ gene in the 19 target isolates using Pearson's correlation coefficient. A Pearson correlation coefficient $(r)$ of 0.841 was calculated between the replicates of concentration/ $\mathrm{OD}_{630 \mathrm{~nm}}$ for HysA production and the fold of change in hys $A$ mRNA expression for each isolate. The calculated $r$ indicates a significant positive agreement between plate assay method and the quantitative assay of mRNA expression using $\mathrm{qPCR}$ at either $\mathrm{P}<0.05$ (Critical $\mathrm{r}$ value $=0.444$ ) or $\mathrm{P}<0.001$ (Critical $\mathrm{r}$ value $=0.679$ )

\section{Conclusion}

In conclusion, we established for the first time a protocol and primers for the qPCR analysis of the hysA mRNA expression in $S$. aureus. Moreover, our work showed the agreement between the phenotypic assay of HysA production via plate assay and hys $A$ expression in $S$. aureus. Future work will be done to correlate the virulence of $S$. aureus in infected animal models and the hys $A$ expression analysis using the qPCR protocol of this study.

\section{Funding}

This work received no specific grant from any funding agency.

\section{Conflict of Interest}

The authors declare that they have no conflict of interest.

\section{References}

[1] Styers, D., Sheehan, D.J., Hogan, P. and Sahm, D.F. (2006) Laboratory-Based Surveillance of Current Antimicrobial Resistance Patterns and Trends among Staphylococcus aureus: 2005 Status in the United States. Annals of Clinical Microbiology and Antimicrobials, 5, 2. https://doi.org/10.1186/1476-0711-5-2

[2] Hoerr, V., Franz, M., Pletz, M.W., Diab, M., Niemann, S., Faber, C., Doenst, T., Schulze, P.C., Deinhardt-Emmer, S. and Loffler, B. (2018) S. aureus Endocarditis: Clinical Aspects and Experimental Approaches. International Journal of Medical Microbiology. https://doi.org/10.1016/j.ijmm.2018.02.004 
[3] Heriot, G.S., Tong, S.Y., Cheng, A.C. and Liew, D. (2018) What Risk of Endocarditis Is Low Enough to Justify the Omission of Transoesophageal Echocardiography in Staphylococcus aureus Bacteraemia? A Narrative Review. Clinical Microbiology and Infection. https://doi.org/10.1016/j.cmi.2018.03.027

[4] Lacey, K.A., Geoghegan, J.A. and McLoughlin, R.M. (2016) The Role of Staphylococcus aureus Virulence Factors in Skin Infection and Their Potential as Vaccine Antigens. Pathogens, 5, 22.

[5] Powers, M.E. and Bubeck Wardenburg, J. (2014) Igniting the Fire: Staphylococcus aureus Virulence Factors in the Pathogenesis of Sepsis. PLoS Pathogens, 10, e1003871. https://doi.org/10.1371/journal.ppat.1003871

[6] Kong, C., Chee, C.F., Richter, K., Thomas, N., Abd Rahman, N. and Nathan, S. (2018) Suppression of Staphylococcus aureus Biofilm Formation and Virulence by a Benzimidazole Derivative, UM-C162. Scientific Reports, 8, 2758.

https://doi.org/10.1038/s41598-018-21141-2

[7] Stern, R. and Jedrzejas, M.J. (2006) Hyaluronidases: Their Genomics, Structures, and Mechanisms of Action. Chemical Reviews, 106, 818-839.

https://doi.org/10.1021/cr050247k

[8] Hart, M.E., Tsang, L.H., Deck, J., Daily, S.T., Jones, R.C., Liu, H., Hu, H., Hart, M.J. and Smeltzer, M.S. (2013) Hyaluronidase Expression and Biofilm Involvement in Staphylococcus aureus UAMS-1 and Its sarA, agr and sarA agr Regulatory Mutants. Microbiology, 159, 782-791. https://doi.org/10.1099/mic.0.065367-0

[9] Hynes, W.L. and Walton, S.L. (2000) Hyaluronidases of Gram-Positive Bacteria. FEMS Microbiology Letters, 183, 201-207. https://doi.org/10.1111/j.1574-6968.2000.tb08958.x

[10] Girish, K.S. and Kemparaju, K. (2007) The Magic Glue Hyaluronan and Its Eraser Hyaluronidase: A Biological Overview. Life Science, 80, 1921-1943. https://doi.org/10.1016/j.lfs.2007.02.037

[11] Jiang, D., Liang, J. and Noble, P.W. (2011) Hyaluronan as an Immune Regulator in Human Diseases. Physiological Reviews, 91, 221-264. https://doi.org/10.1152/physrev.00052.2009

[12] Sonoda, M., Harwood, F.L., Amiel, M.E., Moriya, H., Temple, M., Chang, D.G., Lottman, L.M., Sah, R.L. and Amiel, D. (2000) The Effects of Hyaluronan on Tissue Healing after Meniscus Injury and Repair in a Rabbit Model. The American Journal of Sports Medicine, 28, 90-97. https://doi.org/10.1177/03635465000280012801

[13] Lowy, F.D. (1998) Staphylococcus aureus Infections. The New England Journal of Medicine, 339, 520-532. https://doi.org/10.1056/NEJM199808203390806

[14] Makris, G., Wright, J.D., Ingham, E. and Holland, K.T. (2004) The Hyaluronate Lyase of Staphylococcus aureus-A Virulence Factor? Microbiology, 150, 2005-2013. https://doi.org/10.1099/mic.0.26942-0

[15] Smith, R.F. and Willett, N.P. (1968) Rapid Plate Method for Screening Hyaluronidase and Chondroitin Sulfatase-Producing Microorganisms. Journal of Applied Microbiology, 16, 1434-1436.

[16] Joslyn, D.A. and Galbraith, M. (1947) A Turbidimetric Method for the Assay of Antibiotics. Journal of Bacteriology, 54, 26.

[17] Vercruysse, K.P., Lauwers, A.R. and Demeester, J.M. (1995) Absolute and Empirical Determination of the Enzymatic Activity and Kinetic Investigation of the Action of Hyaluronidase on Hyaluronan Using Viscosimetry. Biochemical Journal, 306, 153-160. https://doi.org/10.1042/bj3060153 
[18] Muckenschnabel, I., Bernhardt, G., Spruss, T., Dietl, B. and Buschauer, A. (1998) Quantitation of Hyaluronidases by the Morgan-Elson Reaction: Comparison of the Enzyme Activities in the Plasma of Tumor Patients and Healthy Volunteers. Cancer Letters, 131, 13-20. https://doi.org/10.1016/S0304-3835(98)00196-7

[19] Steiner, B. and Cruce, D. (1992) A Zymographic Assay for Detection of Hyaluronidase Activity on Polyacrylamide Gels and Its Application to Enzymatic Activity Found in Bacteria. Analytical Biochemistry, 200, 405-410.

https://doi.org/10.1016/0003-2697(92)90487-R

[20] Duthie, E.S. and Lorenz, L.L. (1952) Staphylococcal Coagulase; Mode of Action and Antigenicity. Journal of General Microbiology, 6, 95-107.

[21] Duquenne, M., Fleurot, I., Aigle, M., Darrigo, C., Borezée-Durant, E., Derzelle, S., Bouix, M., Deperrois-Lafarge, V. and Delacroix-Buchet, A. (2010) Tool for Quantification of Staphylococcal Enterotoxin Gene Expression in Cheese. Applied and Environmental Microbiology, 76, 1367-1374. https://doi.org/10.1128/AEM.01736-09

[22] Pfaffl, M.W. (2001) A New Mathematical Model for Relative Quantification in Real-Time RT-PCR. Nucleic Acids Research, 29, e45. https://doi.org/10.1093/nar/29.9.e45

[23] Choudhuri, K.K. and Chakrabarty, A.N. (1969) Hyaluronate Lyase Activity of Staphylococci. Indian Journal of Experimental Biology, 7, 183-185.

[24] Essers, L. and Radebold, K. (1980) Rapid and Reliable Identification of Staphylococcus aureus by a Latex Agglutination Test. Journal of Clinical Microbiology, 12, 641-643.

[25] Hart, M.E., Hart, M.J. and Roop, A.J. (2009) Genotypic and Phenotypic Assessment of Hyaluronidase among Type Strains of a Select Group of Staphylococcal Species. International Journal of Microbiology, 2009, Article ID: 614371. https://doi.org/10.1155/2009/614371

[26] Boswihi, S.S., Udo, E.E. and Al-Sweih, N. (2016) Shifts in the Clonal Distribution of Methicillin-Resistant Staphylococcus aureus in Kuwait Hospitals: 1992-2010. PLoS $O N E, 11, \mathrm{e} 0162744$.

[27] Khaledi, A., Schniederjans, M., Pohl, S., Rainer, R., Bodenhofer, U., Xia, B., Klawonn, F., Bruchmann, S., Preusse, M., Eckweiler, D., Dotsch, A. and Haussler, S. (2016) Transcriptome Profiling of Antimicrobial Resistance in Pseudomonas aeruginosa. Antimicrobial Agents and Chemotherapy, 60, 4722-4733. https://doi.org/10.1128/AAC.00075-16

[28] Janjua, H.A., Segata, N., Bernabo, P., Tamburini, S., Ellen, A. and Jousson, O. (2012) Clinical Populations of Pseudomonas aeruginosa Isolated from Acute Infections Show a Wide Virulence Range Partially Correlated with Population Structure and Virulence Gene Expression. Microbiology, 158, 2089-2098.

https://doi.org/10.1099/mic.0.056689-0

[29] Zelezniak, A., Sheridan, S. and Patil, K.R. (2014) Contribution of Network Connectivity in Determining the Relationship between Gene Expression and Metabolite Concentration Changes. PLOS Computational Biology, 10, e1003572.

https://doi.org/10.1371/journal.pcbi.1003572

[30] Caldwell, R., Sapolsky, R., Weyler, W., Maile, R.R., Causey, S.C. and Ferrari, E. (2001) Correlation between Bacillus subtilis scoC Phenotype and Gene Expression Determined Using Microarrays for Transcriptome Analysis. Journal of Bacteriology, 183, 7329-7340. https://doi.org/10.1128/JB.183.24.7329-7340.2001 


\section{Supplementary Materials Description}
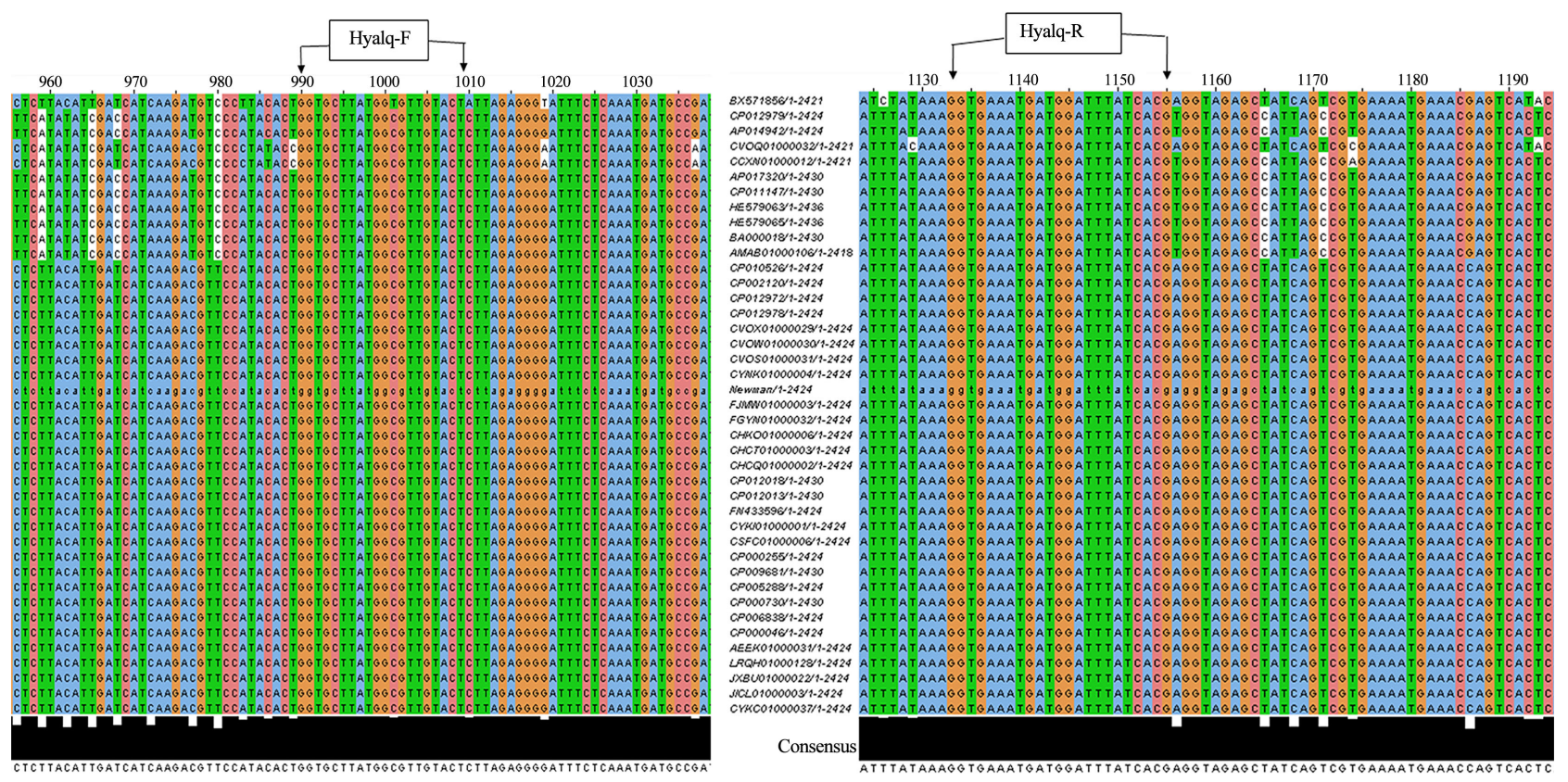

Figure S1. Multisequence alignment of hyaluronidase DNA sequences of 41 strains $S$. aureus obtained from the Genbank using Clustal omega tool. The forward primer (Hyalq-F) and reverse primer (Hyalq-R) were precisely designed from the conserved regions of the aligned sequences. The sequence of $S$. aureus strain Newman is indicated by lowercase letters of nucleotides. 